mansasa

glyndîn

Glyndŵr University

Glyndŵr University Research Online

Psychology

Psychology

$12-1-2010$

\title{
Shaping attitude toward Christianity among year seven pupils: the influence of sex, church, home and primary school
}

Tracy Swindells

Warwick Religions and Education Research Unit

Leslie J. Francis

University of Warwick, leslie.francis@warwick.ac.uk

Mandy Robbins

Glyndwr University, mandy.robbins@glyndwr.ac.uk

Follow this and additional works at: http://epubs.glyndwr.ac.uk/psyc

Part of the Other Psychology Commons, and the Religious Thought, Theology and Philosophy of Religion Commons

Copyright (c) 2010 Taylor and Francis Routledge.

This is an electronic version of an article published in Swindells, T., Francis, L. J. and Robbins, M. (2010) 'Shaping attitude toward Christianity among year seven pupils: the influence of sex, church, home and primary school', Journal of Beliefs \& Values, 31(3), 343- 348 information for the final version of the article as published in the print edition of the Journal of Beliefs \& Values is available online at: www.tandfonline.com/ and the article can be located at http://dx.doi.org/10.1080/

13617672.2010 .521013

\section{Recommended Citation}

Swindells, T., Francis, L. J. and Robbins, M. (2010) 'Shaping attitude toward Christianity among year seven pupils: the influence of sex, church, home and primary school'. Journal of Beliefs \& Values, 31(3), 343- 348

This Article is brought to you for free and open access by the Psychology at Glyndŵr University Research Online. It has been accepted for inclusion in Psychology by an authorized administrator of Glyndŵr University Research Online. For more information, please contact d.jepson@glyndwr.ac.uk. 


\begin{abstract}
Shaping attitude toward Christianity among year seven pupils: the influence of sex, church, home and primary school.
\end{abstract}

\author{
Tracy Swindells \\ Warwick Religions and Education Research Unit
}

Leslie J Francis*

University of Warwick

Mandy Robbins

University of Warwick
Author note:
*Corresponding author:
Leslie J Francis
Warwick Religions \& Education Research Unit
Institute of Education
The University of Warwick
Coventry CV4 7AL United Kingdom
Tel: $\quad+44(0) 2476522539$
Fax: $\quad$ +44 (0)2476572638
Email: leslie.francis@warwick.ac.uk




\begin{abstract}
This study set out to examine the differences in attitude toward Christianity among year seven secondary school pupils who had undertaken their primary education either in a Church of England voluntary aided school or a non-denominational state-maintained school. Data were provided by 492 year seven pupils attending three Church of England voluntary secondary schools and comparison is made between 288 pupils who had transferred from Anglican voluntary aided primary schools and 164 from nondenominational state-maintained schools. After taking into account the effects of sex, pupil church attendance, paternal church attendance, and maternal church attendance, the data found no effect from attending a Church of England voluntary aided primary school.
\end{abstract} Keywords: 


\section{Introduction}

In the mid-1970s, Francis (1978a, 1978b) argued for the primacy of the attitudinal dimension of religion for explaining the correlates, antecedents and consequences of individual differences in religiosity during childhood and adolescence, and into adulthood. He also proposed the 24-item Likert-type Francis Scale of Attitude toward Christianity as a method by which disparate empirical studies could be integrated in order to construct a coherent picture of the location of religiosity throughout the life-span. By the mid 1990s, Kay and Francis (1996) drew together around 100 independent studies that had used this instrument to assess the developing picture, and the number of studies reported in the literature has continued to expand since then. In terms of the antecedents of individual differences in religiosity during adolescence, attention has focused on four key areas usefully described as: personal, church, family, and school.

In terms of personal factors, the international research literature has consistently pointed to the importance of sex differences. At least within the Christian context, females report higher levels of religiosity in general and more positive attitudes toward religion in particular (Francis, 1997), although there remains debate regarding the psychological mechanism underpinning this observed difference (Francis, 2005).

In terms of church, the international research literature has consistently pointed to the importance of the frequency of church attendance. More frequent attendance is associated, overall, with more positive attitudes toward religion, at least within the Christian context (Francis, Lewis, Philipchalk, Brown, \& Lester, 1995). This relationship, however, remains complex in the light of a range of complicating personal and contextual factors. 
In terms of family, the international research literature has consistently pointed to the importance of family example in supporting the young person's personal experience of church attendance. Multivariate models have shown the additional predictive power of both maternal and paternal church attendance (after taking the young person's own level of church attendance into account) in contributing to more positive attitudes toward religion among adolescents (Francis \& Gibson, 1993). This relationship also remains complex with different effects flowing from mothers and from fathers.

In terms of school, the situation in England and Wales is highly distinctive. Following the 1944 Education Act, the Anglican Church and the Catholic Church have continued to invest in voluntary aided schools within the state-maintained sector. According to the provisions of this Act, voluntary aided schools provide for the Churches opportunities to appoint a majority of governors, to shape the requirements for the headteacher, to shape the admissions policy, and to provide denominationally informed religious education and school worship (Dent, 1947). During the 1970s and 1980s, a series of studies set out to establish the extent to which Anglican voluntary schools contributed to shaping attitudes toward religion among their year six pupils compared with non-denominational state-maintained schools (after taking into account personal, church, and family-related factors). Data from these studies reported by Francis (1979, 1986a,1987) found that pupils educated in Anglican schools either reported attitudes toward religion indistinguishable from pupils educated in non-denominational schools, or reported significantly less positive attitudes.

While previous research has compared attitudes toward religion among year six pupils, previous research has not attempted to chart the detectable influence of Anglican 
voluntary primary schools on pupils during their subsequent secondary education. The present study has been designed to address this interesting and important research question, properly located within the broader context of recognizing the contribution of personal, church, and family factors. The study has been situated within the Diocese of Blackburn in view of the particularly high number of Anglican voluntary aided primary schools and voluntary aided secondary schools, reflecting diocesan policy following the 1944 Education Act (Francis, 1986b).

\section{Method}

\section{Procedure}

Three neighbouring Anglican voluntary aided secondary schools agreed to administer the survey throughout the year seven classes (age range 11 to 12 years) during religious education lessons. The survey was introduced as a project concerned to listen to pupils' views about religious education and about religion in general. The pupils were assured of anonymity and confidentiality. Although given the opportunity to opt out of the project, no pupils decided not to participate.

\section{Measures}

Attitude toward Christianity was assessed by the 24-item Likert type instrument proposed by Francis (1978a, 1978b) and supported for use among secondary school pupils by a number of studies, including Francis (1989). Each item was assessed on a five-point scale: agree strongly, agree, not certain, disagree, and disagree strongly. 
Church attendance was assessed by three questions (personal, maternal and paternal), each rated on a five-point scale: nearly every week, at least once a month, sometimes, once or twice a year, and never.

\section{Sample}

Completed surveys were submitted by 492 pupils, 224 boys and 268 girls. In terms of their primary school experience, 164 pupils had attended non-denominational state- maintained school, 288 Anglican voluntary aided schools, 15 Anglican voluntary controlled schools, 21 Catholic voluntary aided schools, and 4 independent schools.

\section{Data analysis}

Data were analysed by means of SPSS employing the frequency, reliability, correlation and regression routines. The following analyses were based on the 288 pupils who attended Anglican voluntary aided primary schools and the 164 pupils who attended non-denominational state-maintained primary schools.

\section{Results}

Among this group of young people the Francis Scale of Attitude toward Christianity performed with characteristically high levels of internal consistency reliability, generating an alpha coefficient (Cronbach, 1951) of .96. Table 1 sets out the correlation matrix for the six key variables included in the study: attitude toward Christianity, maternal church attendance, paternal church attendance, pupil church attendance, pupil sex $($ male $=1$; female $=2)$ and type of primary school attended (nondenominational = 1; Church of England voluntary aided $=2$ ). These data indicate that a more positive attitude toward Christianity is associated with being female, with frequent church attendance, with frequent maternal church attendance, and with frequent paternal 
church attendance. However, there was no significant association between attitude toward Christianity and the type of primary school attended. These data also confirm significant associations between pupil church attendance, maternal church attendance, and paternal church attendance. Moreover, although pupils who attended a Church of England voluntary aided primary school did not hold a significantly more positive or less positive attitude toward Christianity in comparison with pupils who attended a nondenominational school, they did attend church with significantly lower frequency.

[Insert tables 1 and 2 about here]

Table 2 takes the data analysis one step further by exploring the simultaneous and cumulative impact of the five predictor variables on attitude toward Christianity. The predictor variables were entered into the equation in the fixed order of sex, pupil church attendance, maternal church attendance, and paternal church attendance, before examining the influences of school type. These data confirm that school type is not a significant factor in shaping attitudes toward Christianity among this group of year seven pupils.

\section{Discussion and conclusion}

This study set out to assess whether variance in year seven pupils' attitudes toward Christianity could be attributed to previous attendance at a Church of England voluntary aided primary school. Comparison was made between 288 year seven pupils who had previously attended a Church of England voluntary aided primary school and 164 who had previously attended a non-denominational state-maintained primary school, and who were currently attending three Church of England voluntary secondary schools. Multiple regression analysis was employed to take into account the effects of sex, pupil 
church attendance, maternal church attendance, and paternal church attendance, before testing for school effects. The data suggest four main conclusions.

First, within the terms of the regression model, the church emerged as the major influence on shaping attitudes toward Christianity among year seven pupils, a point clearly made by the standardised regression coefficient. Young people who attend church hold significantly more positive attitudes toward Christianity than young people who do not attend church.

Second, within the terms of the regression model, the family emerged as a significant influence on shaping attitudes toward Christianity among year seven pupils in addition to the influence of church. According to the data what counts in this regard is the example of mother rather than the example of father. Young people who attend church and whose mother attends church hold significantly more positive attitudes toward Christianity than young people who attend church but whose mother does not attend church.

Third, although sex is a factor implicated in shaping attitudes toward Christianity, it is of much less significance than either church or family. Indeed, according to the standardized regression coefficient, sex ceases to be a significant predictor within the multivariate context recognizing the influence of church and family.

Fourth, within the terms of the regression model, the most important conclusion from these data concerns the lack of association between the type of primary school attended and attitudes toward Christianity among year seven pupils. This finding may be open to either positive or negative interpretation within the ongoing debate regarding the 
identity and purpose of Anglican voluntary aided schools in England and Wales (Francis 2000).

From the time of the Durham Report (1970) onwards, the Church of England has distinguished between opposing objectives for church schools: general and domestic. The general objective concerns the service of the nation through the provision of schools designated to the education of all children, irrespective of race, ability or religion. The domestic objective concerns the nurture within the faith of children from Anglican backgrounds. From secularist perspectives such church schools have been subject to two main objections. On the one hand, church schools have been accused of employing their religious foundation to indoctrinate or to proselytise. The present data can help to defend Anglican voluntary aided primary schools against such an accusation. On the other hand, church schools have been accused of neglecting their religious purpose in favour of creating elitist communities (admitting pupils on the basis of non-religious criteria). The present data may prove less useful in defending Anglican voluntary aided primary schools against this accusation.

The strength of the present study is that it explored the research question in an area of England where there is a relatively high density of Anglican voluntary aided primary schools and where there is a strong presence of Anglican voluntary secondary schools into which pupils educated in those primary schools can transfer, namely the Diocese of Blackburn. The weakness, however, is that the research was limited to only three of the Anglican voluntary secondary schools within that diocese. Further research is needed to extend this pioneering study first throughout the Diocese of Blackburn and then within other geographical areas. 


\section{References}

Cronbach, L. J. (1951). Coefficient alpha and the internal structure of tests. Psychometrika, 16, 297-334.

Dent, H. J. (1947). The Education Act 1944: Provisions, possibilities and some problems (3rd ed.). London: University of London Press.

Durham Report. (1970). The Fourth R: the report of the commission on religious education in schools. London: National Society and SPCK.

Francis, L. J. (1978a). Attitude and longitude: A study in measurement. Character Potential, 8, 119-130.

Francis, L. J. (1978b). Measurement reapplied: Research into the child's attitude towards religion. British Journal of Religious Education, 1, 45-51.

Francis, L. J. (1979). School influence and pupil attitude towards religion. British Journal of Educational Psychology, 49, 107-123.

Francis, L.J. (1986a). Denominational schools and pupil attitude towards Christianity. British Educational Research Journal, 12, 145-152.

Francis, L. J. (1986b). Partnership in Rural Education: church schools and teacher attitudes. London: Collins Liturgical Publications.

Francis, L. J. (1987). Religion in the primary school: Partnership between church and state? London: Collins Liturgical Publications.

Francis, L. J. (1989). Measuring attitude towards Christianity during childhood and adolescence. Personality and Individual Differences, 10, 695-698.

Francis, L. J. (1997). The psychology of gender differences in religion: A review of empirical research. Religion, 27, 81-96. 
Francis, L. J. (2000). The domestic and the general function of Anglican schools in England and Wales. International Journal of Education and Religion, 1, 100-121.

Francis, L. J. (2005). Gender role orientation and attitude toward Christianity: A study among older men and women in the United Kingdom. Journal of Psychology and Theology, 33, 179-186.

Francis, L. J. \& Gibson, H. M. (1993). Parental influence and adolescent religiosity: a study of church attendance and attitude toward Christianity among adolescents 11 to 12 and 15 to 16 years old. International Journal for the Psychology of Religion, $3,241-253$.

Francis, L. J., Lewis, J. M., Philipchalk, R., Brown, L. B., \& Lester, D. (1995). The internal consistency reliability and construct validity of the Francis scale of attitude towards Christianity (adult) among undergraduate students in the UK, USA, Australia and Canada. Personality and Individual Differences, 19, 949-953.

Kay, W. K., \& Francis, L. J. (1996). Drift from the churches: Attitude toward Christianity during childhood and adolescence. Cardiff: University of Wales Press. 
Table 1

Correlation Matrix

\begin{tabular}{llllll}
\hline & Attitude & Primary & Father & Mother & Pupil \\
\hline Sex & $.13^{* *}$ & -.01 & -.03 & .07 & $.15^{* * *}$ \\
Pupil church attendance & $.48^{* * * *}$ & $-.15^{* * *}$ & $.15^{* *}$ & $.36 * * *$ & \\
Mother church attendance & $.32^{* * * *}$ & -.04 & $.47 * * *$ & & \\
Father church attendance & $.47^{* * *}$ & -.06 & & & \\
Church primary school & .04 & & & & \\
\hline
\end{tabular}


Table 2

Regression model

\begin{tabular}{|c|c|c|c|c|c|c|c|}
\hline & \multirow[b]{2}{*}{$\mathrm{r}^{2}$} & \multicolumn{2}{|c|}{ increase } & \multirow[b]{2}{*}{$p<$} & \multirow[b]{2}{*}{ Beta } & \multirow[b]{2}{*}{$\mathrm{t}$} & \multirow[b]{2}{*}{$p<$} \\
\hline & & $\mathrm{r}^{2}$ & $\mathrm{~F}$ & & & & \\
\hline Sex & .016 & .016 & 7.3 & .01 & .058 & 1.4 & NS \\
\hline Pupil church attendance & .230 & .214 & 122.6 & .001 & .411 & 9.1 & .001 \\
\hline Mother church attendance & .255 & .025 & 14.7 & .001 & .126 & 2.6 & .01 \\
\hline Father church attendance & .261 & .006 & 3.4 & NS & .086 & 1.8 & NS \\
\hline Church primary school & .261 & .000 & 0.1 & NS & -.011 & -0.3 & NS \\
\hline
\end{tabular}

